
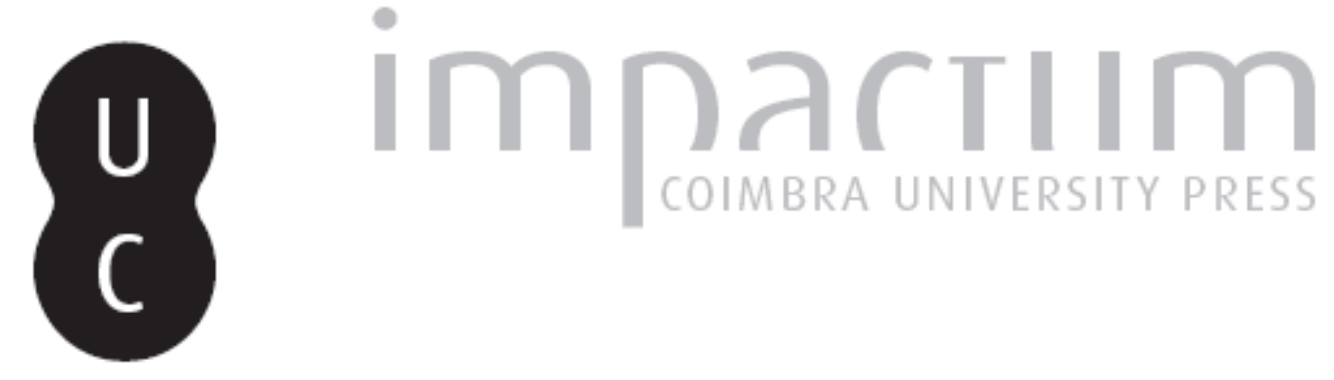

\title{
A Academia Brasílica dos Renascidos e o governo político da América portuguesa (1759): notas sobre as contradições do cosmopolitismo acadêmico lusoamericano
}

Autor(es): Kantor, Iris

Publicado por: Imprensa da Universidade de Coimbra

URL persistente:

URI:http://hdl.handle.net/10316.2/43715

DOI:

DOI:https://doi.org/10.14195/2183-8925_24_2

Accessed : $\quad$ 26-Apr-2023 10:40:45

A navegação consulta e descarregamento dos títulos inseridos nas Bibliotecas Digitais UC Digitalis, UC Pombalina e UC Impactum, pressupõem a aceitação plena e sem reservas dos Termos e Condições de Uso destas Bibliotecas Digitais, disponíveis em https://digitalis.uc.pt/pt-pt/termos.

Conforme exposto nos referidos Termos e Condições de Uso, o descarregamento de títulos de acesso restrito requer uma licença válida de autorização devendo o utilizador aceder ao(s) documento(s) a partir de um endereço de IP da instituição detentora da supramencionada licença.

Ao utilizador é apenas permitido o descarregamento para uso pessoal, pelo que o emprego do(s) título(s) descarregado(s) para outro fim, designadamente comercial, carece de autorização do respetivo autor ou editor da obra.

Na medida em que todas as obras da UC Digitalis se encontram protegidas pelo Código do Direito de Autor e Direitos Conexos e demais legislação aplicável, toda a cópia, parcial ou total, deste documento, nos casos em que é legalmente admitida, deverá conter ou fazer-se acompanhar por este aviso.

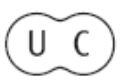



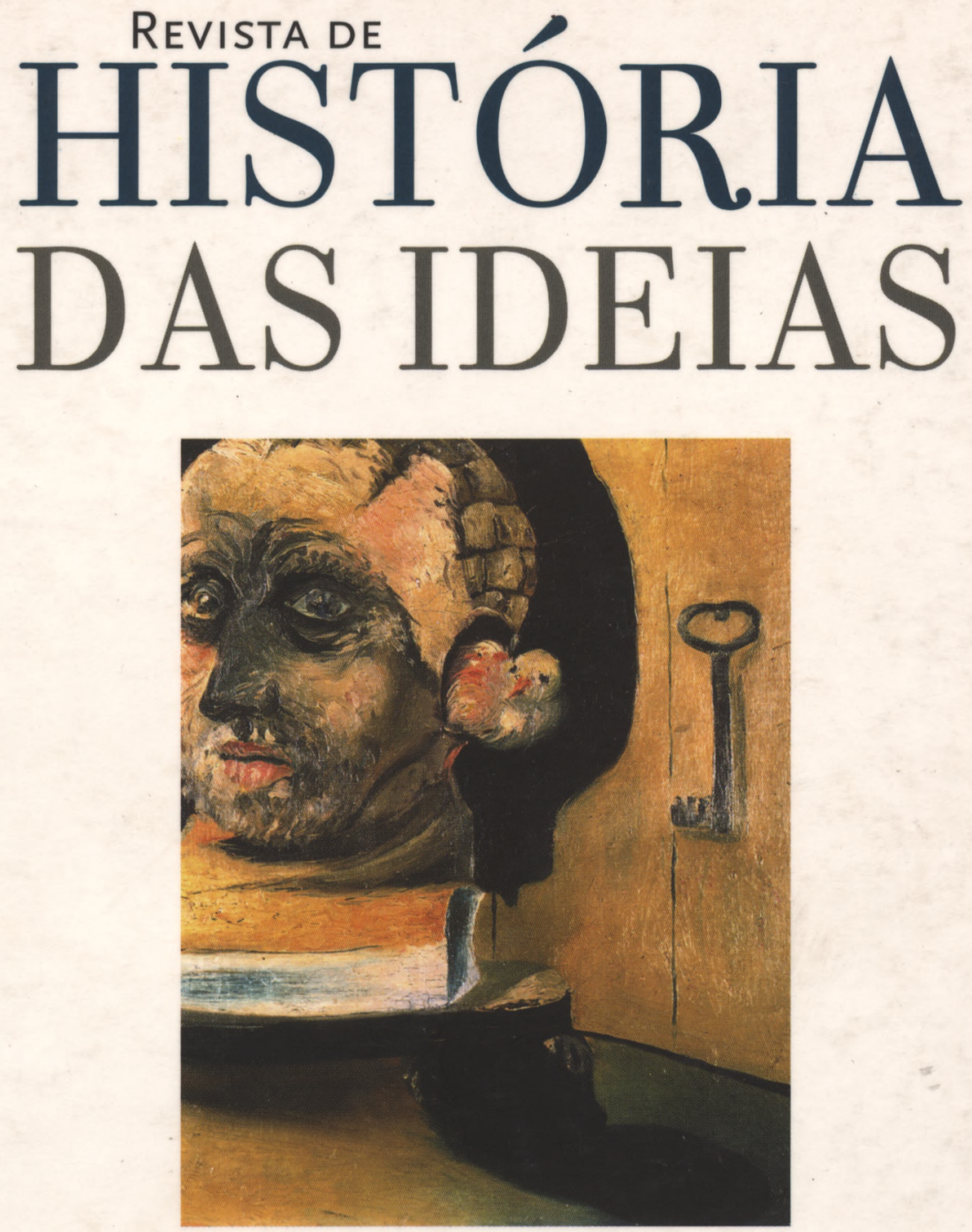

OS INTELECTUAIS E OS PODERES

Volume 24, 2003

INSTITUTO DE HISTÓRIA E TEORIA DAS IDEIAS

Faculdade de Letras da Universidade de Coimbra 


\title{
A ACADEMIA BRASÍLICA DOS RENASCIDOS E O GOVERNO POLÍTICO DA AMÉRICA PORTUGUESA (1759) Notas sobre as contradições do cosmopolitismo acadêmico lusoamericano ${ }^{* *}$
}

\begin{abstract}
"[...] é justo que a mandarem-se pessoas de tão escolhida capacidade, fiquemos com específica notícia do estado em que se acham aqueles sertōes para se poder informar a Sua Majestade, e ao menos será útil para a História da América"(1).

"Escreve Eliano que os príncipes de Mitilene introduziram nos seus estados a ignorância para castigo dos povos, que se rebelavam, para cujo efeito desterraram os doutos e exterminaram as academias: e afirma Plutarco que Cyro deu o mesmo castigo aos povos da Lydia, e Xerxes aos de Babilônia [...] Se a proscrição das letras é um dos maiores castigos que se pode dar a um reino, claro está que o estabelecimento das ciências é um dos maiores benefícios, com que se pode procurar a felicidade de uma república, donde será sempre maior serviço para uma monarquia o estender-lhe os limites do engenho, do que adiantar-lhe as balizas do Império"(2).
\end{abstract}

* Universidade de São Paulo.

** Agradeço a leitura crítica e sugestões de István Jancsó e Tiago C. P. dos Reis Miranda.

(1) AHU-ACL-CU-005, cx. 137, d. 10620. "Parecer do conselheiro José Mascarenhas Pacheco Pereira Coelho de Melo sobre o modo de estabelecimento das aldeias de índios que sua magestade manda erigir em vilas". Bahia, 27/9/1758.

(2) Domingos Loreto Couto, Desagravos do Brasil e Glórias de Pernambuco (1757). Ed. Fac-similar. Recife, Fundação de Cultura Cidade do Recife, 1981, (primeira edição: Anais da Biblioteca Nacional, 1904), p. 357. 
Às vésperas da expulsão da Companhia de Jesus dos domínios portugueses, o conselheiro ultramarino José Mascarenhas Pacheco Pereira Coelho de Melo - enviado especial de Pombal para cumprir essa tarefa no Estado do Brasil - propunha a aplicação de um inquérito nos aldeamentos indígenas por "pessoas de escolhida capacidade". O levantamento sobre a situação econômica, demográfica, lingüística e geográfica nos aldeamentos indígenas tinha o objetivo de orientar a implementação do Diretório dos Índios (1755-1758). Embora a aplicação de questionários fosse freqüente em todo o império português, o conselheiro alimentava a expectativa de que as informações recolhidas pudessem ser igualmente úteis para escrever uma História da América portuguesa.

Em maio de 1759, logo após os festejos públicos, realizados na cidade de Salvador, em tributo a $\mathrm{D}$. José I pelo fracasso do atentado contra sua vida, José Mascarenhas tomara a iniciativa de reunir as elites locais para fundar uma Academia de História, que viria a ser chamada de Academia Brasílica dos Renascidos ${ }^{(3)}$. O conselheiro ultramarino defendia a necessidade de uma academia para que se pudesse assegurar a transmissão dos conhecimentos geográficos, históricos e etnográficos acumulados pelos missionários jesuítas ao longo de 200 anos de missionação. À Academia seria encaminhado o preciosíssimo espólio de livros, obras manuscritas, mapas e diplomas legais depositados nas livrarias dos Colégios $^{(4)}$. Dadas as circunstâncias que envolveram a resistência dos missionários jesuítas às comissões de demarcação do Tratado de Madri (1750), ele aquilatava a importância das informações

(3) Alberto Lamego, A Academia Brazilica dos Renascidos: sua fundação e trabalhos inéditos, Paris/Bruxelas, Edition d'Árt Gaudio, 1923; Regina Duarte Talhe, A Academia Brasilica dos Renascidos da Baía: sua importância histórico cultural, 2 vol., Universidade Clássica de Lisboa, 1964. (dissertação); Iris Kantor, De Esquecidos e Renascidos: a historiografia acadêmica luso-americana (1724-59), Universidade de São Paulo, (doutoramento), 2002.

(4) Em 1759, o espólio das livrarias jesuíticas americanas alcançava a estimativa de 60 mil volumes, sem contabilizar os livros manuscritos. A dispersão das livrarias acabou sendo inevitável, embora os acadêmicos tenham procurado conservar os acervos jesuíticos baianos sob a sua custódia. A maior parte das livrarias foi vendida e remetida a Lisboa, a exemplo dos acervos dos Colégios do Pará. Mark L. Grover. "The book and the conquest: jesuit libraries in colonial Brazil", Libraries and Cultures, Austin, vol. 28, 1993. pp. 266-283. 
geopolíticas que corriam o risco de serem dispersas ou alienadas em mãos inimigas após a expulsão dos jesuítas ${ }^{(5)}$. Temendo uma reação local às medidas, ele advertia seus pares com uma sentença grega: "[...] nos séculos futuros se não há de averiguar em quanto tempo se fizeram as ações grandes, se não o modo e o como se executarão"(6).

O conselheiro pretendia minimizar o traumatismo social causado pelo fechamento de 25 residências, 36 missões e 17 colégios, sem contar com os seminários menores e escolas de ler e escrever instaladas nos aldeamentos jesuíticos ${ }^{(7)}$. De forma que, em face do impacto das medidas regalistas, a fundação de uma instituição acadêmica parecia adequar-se perfeitamente à intenção de formar novos quadros para exercerem os cargos da administração pública imperial ${ }^{(8)}$. E, uma vez que, as diretrizes da política pombalina procuravam aumentar a capacidade de intervenção da Coroa por intermédio da criação de órgãos locais colegiados - as

(5) Segundo José Honório Rodrigues, uma carta régia de 1761 determinou que os papéis dos jesuítas fossem confiados aos bispos das dioceses. Jorge Couto sugere que os fundos jesuíticos teriam sido transferidos para a Real Mesa Censória (1768), vindo a compor o acervo da Real Biblioteca Pública da Corte (1794). José Honório Rodrigues, A pesquisa histórica no Brasil, Rio de Janeiro, Departamento de Imprensa Nacional, 1952, p. 59; José Jorge da Costa Couto. O Colégio dos Jesuitas do Recife e o destino do seu patrimônio (1759-1777), Lisboa, Mestrado, Universidade de Lisboa, 1990, p. 180; Serafim Leite, História da Cia. de Jesus no Brasil, Lisboa, Rio de Janeiro, Portugália, INL, 1938-1949, t. 5, livros 1, capítulo IV.

(6) AHU-ACL-CU-005, cx. 37, d. 10620, Baía, 27/9/1758.

(7) As informações são de Fernando de Azevedo, A cultura brasileira, Brasília, UNB, 1963, p. 539. Laerte Ramos de Carvalho identificou 9 colégios, 3 seminários, 6 missões e 25 residências somente no Estado do Brasil. Laerte Ramos de Carvalho, As reformas pombalinas da instrução pública, São Paulo, Edusp/Saraiva, 1978; Antônio Alberto Banha de Andrade, "O Marquês de Pombal e o ensino no Brasil", Pombal Revisitado, Lisboa, Editorial Estampa, 1984, pp. 227-241. Veja-se tb: Dauril Alden, The Making of na Enterprise: The Society of Jesus in Portugal, its Empire, and Beyond (1540-1750), California, Stanford University Press, 1996; Paulo de Assunção. Negócios Jesuíticos: A administração dos bens divinos, São Paulo, Edusp, 2003 (no prelo).

(8) Ana Cristina B. Araújo, "Dirigismo cultural e formação das elites no pombalismo", in O Marquês de Pombal e a Universidade, Coimbra, Imprensa da Universidade, 2000, pp. 9-40; Kenneth Maxwell, Marquês de Pombal: paradoxo do iluminismo, tradução Antônio de Pádua Danesi. Rio de Janeiro, Paz e Terra, 1996; Joaquim Veríssimo Serrão, O Marquês de Pombal, Lisboa, Câmara Municipal, 1987, p. 129. 
juntas de comércio, mesas de inspeção e juntas de justiça - que possibilitassem uma maior participação das (nas) elites americanas na implementação das reformas políticas em curso(9).

Alguns meses antes, o secretário do rei, Sebastião José Carvalho de Melo enviara aos conselheiros José Mascarenhas, Manoel Estevão Barbarino e Antonio Azevedo Coutinho uma "instrução secreta" para instalação de uma Mesa de Consciência e Ordens e um Conselho de Estado e Guerra na capitania geral da Bahia. A instituição interina da Mesa de Consciência e Ordens e do Conselho de Guerra agilizava a tomada de decisões in loco, delegando aos enviados especiais poderes extraordinários $^{(10)}$. A Mesa deveria ser dirigida por D. José Botelho de Matos, arcebispo primaz da Bahia; o Conselho, pelo governador geral e vice rei D. Marcos Noronha de Brito ${ }^{(11)}$. Os referidos "tribunais" foram instalados no início de setembro, logo após a chegada de José Mascarenhas em agosto de 1758. Contudo, o primaz do arcebispado encaminhara seu pedido de renúncia ao cargo, resusando-se a colaborar no processo de expulsão dos jesuítas, recolhendo-se à ermida na freguesia de Nossa Senhora da Penha de Itapagipe, onde faleceria em $1767^{(12)}$.

Os conselheiros tinham a incumbência de fazer o inventário geral e o confisco dos bens e rendimentos dos jesuítas, dar provimento dos párocos seculares nas aldeias, estabelecer a demarcação das sesmarias e elevar as vilas indígenas. José Mascarenhas mostrava-se particularmente sensível

(9) Fernando A. Novais, Portugal e Brasil na crise do antigo sistema colonial (1777-1808), São Paulo, Hucitec, 1979 ( capítulo IV: A política colonial).

(10) Ignacio Accioli de Cerqueira e Silva, Memórias Históricas e Políticas da Província da Bahia, anotadas por Braz do Amaral, Imprensa Oficial do Estado, 1925.

(11) "Ofício (minuta) do presidente do Conselho Ultramarino ao secretario da Marinha e Ultramar sobre o regimento a dar aos conselheiros que vão em comissão especial à Bahia." AHU-ACL-CU-005, cx.136, d.10543, 20/5/1758.

(12) José Pedro Paiva alinha D. José Botelho de Mattos ao grupo de bispos que reagiu às ordens do Cardeal Francisco Saldanha da Gama, patriarca de Lisboa. $\mathrm{O}$ arcebispo baiano apresentou sua resignação à diocese em 2 de novembro de 1759. José Pedro Paiva, “Os novos prelados diocesanos nomeados no consulado pombalino", comunicação apresentada ao Congresso Internacional "O Marquês de Pombal e a sua Época", 1999, exemplar cedido pelo autor; cf. Fortunato de Almeida, História da Igreja em Portugal, Barcelos, Cia. Editora do Minho, 1970, vol. 3, p. 604; Pedro Calmon, História do Brasil, Rio de Janeiro, José Olympio, 1959, vol. 4, p. 1152. 
ao papel estratégico que uma Academia poderia assumir nessas circunstâncias, destacava, a utilidade do empresa para o preparo intelectual das futuras elites dirigentes lusoamericanas, assim como na tarefa de escolher os novos párocos e diretores que atuariam nas comunidades indígenas.

O programa de civilização dos ameríndios imposto pelo Diretório dos Indios (1755-58) significou uma mutação na doutrina missionária de justificação da colonização portuguesa, concretizada pela transferência do controle direto das populações indígenas das ordens religiosas para os poderes civis e episcopais ${ }^{(13)}$. A nova legislação impunha a substituição dos missionários por párocos colados, a outorga de direitos municipais às aldeias e a demarcação das sesmarias indígenas, o estímulo à produção agrícola e artesanal, o uso obrigatório da língua portuguesa (e a terminante proibição da língua geral, identificada com a pedagogia jesuítica); e, ainda, pretendia a formação de lideranças políticas nativas para que se pudesse organizar a "república dos índios" e estabelecer as bases do governo indireto daquelas populações ${ }^{(14)}$. O novo status civil transformava os indígenas em súditos da Coroa, de modo que os vassalos indígenas deveriam estar disponíveis para trabalhar, pagar o dízimo, integrar as tropas militares e ocupar as fronteiras litigiosas ${ }^{(15)}$. $\mathrm{O}$ reconhecimento da soberania portuguesa pelos ameríndios tinha transcendência no plano do direito internacional ao transformá-los em titulares de direitos, garantindo-se, nessa medida, o uti-possidetis dos

(13) Luiz Felipe de Alencastro observa que a nova legislação valorizou, pela primeira vez, as virtudes leigas do poder, do trabalho e da cultura, antecipando, nessa medida, as concepções colonialistas praticadas nas últimas décadas do século XIX. Luiz Felipe de Alencastro, Pombal e a civilização do Brasil, São Paulo, Biblioteca Municipal Mário de Andrade, 2002 (palestra).

(14) Maria Helena Ochi Flexor, "Criação da rede urbana na Capitania da Bahia: século XVIII", Universo Urbanístico português (1415-1822), CNCDP, 2000; Heloisa de Almeida, O Diretório dos Índios: um projeto de civilização no Brasil do século XVIII, Brasília, UnB, 1997.

(15) Heloísa Liberalli Belloto. "Política Indigenista no Brasil Colonial (1570-1757)", Revista do IEB , n²29, 1988, pp. 49-59; José Jorge da Costa Couto, O Colégio dos Jesuitas do Recife e o destino do seu patrimônio, Universidade de Lisboa, tese de mestrado, 1990, p. 65; Ângela Domingues, Quando os indios eram vassalos: colonização e relações de poder no Norte do Brasil na segunda metade do século XVIII, Lisboa, CNCDP, 2000. 
territórios então reivindicados pelos portugueses nas negociações internacionais com a Espanha e a França ${ }^{(16)}$.

Todavia, a nova política de civilização dos índios exigia o conhecimento mais aprofundado sobre a diversidade étnica e histórica daquelas populações localizadas em fronteiras mal delimitadas, onde a soberania portuguesa ainda estava por ser fixada ${ }^{(17)}$. Nesse sentido, caberia a hipótese de que a criação da Academia Brasílica dos Renascidos era também uma forma de promover a secularização do conhecimento acumulado sobre as populações indígenas, até então limitadas ao âmbito das ordens religiosas missionárias. E, ao lado dessa vocação indigenista, cabe alinhar uma outra destinada à fixação de uma memória histórica oficial da ocupação territorial portuguesa no continente americano. Essas teriam sido as principais motivações de José Mascarenhas Pacheco Pereira Coelho de Melo, cujo o pai (natural da Bahia) havia ocupado importantes postos na magistratura americana.

Em dia de comemoração do aniversário de D. José I, celebrou-se a fundação da Academia Brasílica dos Renascidos (título que fazia alusão a sua congênere Academia Brasílica dos Esquecidos de 1724) com a devida pompa e circunstância. Na noite de inauguração, a implementação do Diretório dos Índios suscitara manifestações satíricas por parte dos acadêmicos baianos. Ao contrário do otimismo de José Mascarenhas - que não temia evocar Rousseau em suas preleções - os eruditos brasílicos aproveitaram a ocasião para questionar as condições de possibilidade do projeto civilizatório pombalino. Reagindo com acre ironia à política de aculturação civil dos ameríndios, por meio da apresentação de poemas joco-sérios que simulavam uma invasão indígena durante uma sessão acadêmica. O mote do desafio poético era a apresentação de um requerimento em que os índios se dispunham a demonstrar sua lealdade ao monarca através de cantos e danças.

(16) Luís Felipe de Alencastro, Interação européia com as sociedades brasileiras. América, Lisboa, CNCDP, [s.d.]. pp. 97-119; Jaime Cortesão, Alexandre de Gusmão e o Tratado de Madrid, Rio de Janeiro, Ministério das Relações Exteriores, Instituto Rio Branco, 1953, passim.

(17) Marta Rosa Amoroso, "Corsários no caminho fluvial: os Mura do rio Madeira", in Manuela Carneiro da Cunha (Org.), História dos indios no Brasil, $2^{a}$ ed., São Paulo, Cia. das Letras, 1992. 
"Sahio do centro das brenhas

Hum Índio gentil mancebo,

Com seu feitio de gente

De racional só dous dedos:

[...]

Veyo a esta Capital

Donde ouvio os movimentos

De que a nossa Academia

Tinha tão Real objeto

Todo inflamado em corage

Partio aos matos correndo

Donde junta a sua Caterva

Todos lhe fizerao circo

Bem como quando hum Cristão

Chega de Salle (sic) ao Reino

Que se rodeia de povo

A inquirir lhe o captiveiro

[...]

Venho tonto e admirado

Dever a pompa e o asseio

Com que os emboabas festejao

O senhor rei lá do reino

Tua Academia huas festas

Tudo com muito concerto ${ }^{(18)}$

Se, de um lado, a política pombalina de elevação do status civil do indígena abria uma oportunidade de enobrecimento das origens mestiças dos clãs mais antigos estabelecidos na América portuguesa (tornando, a partir de então, desnecessária a falsificação genealógica), enquanto, de outro, as sátiras expressavam uma ambigüidade inerente à condição daquelas elites acadêmicas que se viram obrigadas a reconhecer os direitos das comunidades indígenas ${ }^{(19)}$. A dualidade básica residia no

${ }^{(18)}$ Arquivo da Universidade de Coimbra (AUC). Coleção Conde dos Arcos. Academia Brasílica dos Renascidos, fl. 135.

(19) Refiro-me aqui ao Alvará da lei que aboliu a infâmia dos vassalos do Reino e da América, e seus descendentes, que casassem com índias ou índios. Alvará publicado em 12 de Abril de 1755. 
fato de que a afirmação da ancestralidade indígena constituía uma estratégia de distinção perante os demais grupos adventícios ou de menor sedimentação social na América. Porém, a desqualificação e o rebaixamento intelectual e moral do indígena coevo articulavam-se de maneira contraditória - e até mesmo, inversamente simétrica - com a retórica de heroicização do ancestral indígena, considerado como o herói fundador das principais linhagens da primeira nobreza da terra. Os eruditos baianos reagiram de maneira cética ao indigenismo pombalino, contestando as proposições ilustradas do seu patrono, embora aceitassem sem restrições os avatares de um indianismo de feição nativista, demarcando, nessa medida, sua especificidade e precedência social ${ }^{(20)}$.

Além de demarcar as singularidades da experiência colonizadora na América portuguesa, os acadêmicos baianos demonstravam o seu desejo de afirmação política em face do fortalecimento político e econômico das capitanias do centro-sul (então, sob comando unificado do governador Gomes Freire de Andrade no Rio de Janeiro); e, em detrimento da capital do Vice-Reino em Salvador. Nessa trilha, a iniciativa de escrever uma história geral da ocupação portuguesa na América - contando com a colaboração de membros correspondentes em todas as capitanias e, inclusive, com acadêmicos do Reino e membros espanhóis -, pretendia estimular uma reflexão mais sistemática sobre os direitos e prerrogativas das elites lusoamericanas. Os estatutos dos Renascidos registram a percepção de uma clivagem entre o "português americano" e o "português europeu". A diferença, porém, não tinha sentido disruptivo, mas, pelo contrário, parecia expressar um difuso sentimento americanista que tinha no Império português o seu horizonte político e convergia com o patriotismo imperial ${ }^{(21)}$.

(20) Maria Helena Flexor, "A ociosidade, a vadiagem e a preguiça: o conceito de trabalho no século XVIII", Sociedade Brasileira de Pesquisa Histórica (SBPH), 1997.

(21) István Jancsó e Andrea Slemian, "Uma caso de patriotismo imperial", in Alberto Dines (org.), Correio Brasiliense, São Paulo, IMESP, 2003, vol. XXX; José Jobson de A Arruda. "A prática econômica setecentista no seu dimensionamento regional", Revista Brasileira de História, SP, vol. 5, março 1985, pp. 147-156. 
De modo que, o programa de estudos reivindicava, sobretudo, as prerrogativas e direitos dos colonizadores portugueses naquelas partes do Império português. Reunidos para "servir à Pátria", os acadêmicos brasílicos se dispunham a constituir um centro de preparação intelectual das futuras elites dirigentes luso-americanas. Os membros da Academia planejaram escrever uma "história universal de toda a nossa América portuguesa" para que fosse possível perpetuar a memória do que obraram os vassalos mais beneméritos, acreditando que por intermédio do "mútuo comércio" dos seus sócios se aumentaria a instrução necessária ao governo político da América portuguesa. A expectativa era constituir um corpo representativo de todas as "províncias" luso-americanas, com a participação de acadêmicos das principais academias portuguesas e espanholas, no total de 140 sócios (entre eles: 40 membros efetivos residentes na Bahia e 100 correspondentes de outras partes). Entre as propostas de estudo, os acadêmicos contavam preparar as memórias históricas das capitanias gerais, dos bispados das diferentes ordens religiosas, conventos e recolhimentos, do comércio afirmativo e passivo em toda a América (incluindo o tráfico negreiro e as rendas dos contratos reais), dos tribunais judiciários, das provedorias, dos regimentos militares e, enfim, de toda a legislação respeitante aos domínios americanos. Além dessas memórias institucionais, comprometiam-se a escrever uma história de "todos os índios" na América portuguesa, a história da agricultura (especialmente do açúcar e do tabaco), a história natural e militar e, finalmente, as memórias genealógicas das principais familias "de toda América"(22).

Do ponto de vista territorial, o programa idealizado não só abrangia os domínios luso-americanos, mas também se projetava para além do Atlântico ao incorporar os bispados de Angola e São Tomé e Príncipe (sufragâneos à jurisdição do Arcebispado da Bahia). A proposta dos acadêmicos renascidos era tangível, estruturando-se a partir de rotas mercantis, redes burocráticas civis e eclesiásticas, laços familiares e relações de afinidade intelectual forjadas com o mundo erudito português e europeu. As elites pertencentes aos quadros da academia

(22) Biblioteca Nacional de Lisboa (BNL), Fundo Geral, Ms. Cod. 630, fls. $234 / 250$. 
enredavam-se umas nas outras, o que permitia fluxos de informação entre as diferentes partes do Império ultramarino ${ }^{(23)}$.

\section{Territorialidade, remuneração de serviços e programa historiográfico}

Durante o consulado pombalino, diversas ações governamentais procuraram promover a afirmação da soberania territorial portuguesa na América, entre elas a expansão da rede de vilas, julgados e paróquias; a incorporação das capitanias donatárias ao patrimônio da Coroa e a redefinição da geografia política através da distinção entre capitanias gerais e subalternas. Na esfera da administração pública local, a Coroa intentava modificar o regime de concessão da propriedade de ofícios públicos e patentes militares. As autoridades metropolitanas também davam curso às tentativas de regulamentação da propriedade fundiária (limitação da extensão das sesmarias continentais, revogando, sem sucesso e por um curto período, o regime de sesmarias em 1753-1754(24). Tais diretrizes faziam parte de uma política geral de reenquadramento jurídico-administrativo dos domínios americanos ${ }^{(25)}$.

(23) J. Russel Wood, "Prefácio", in João Fragoso, M. Fernanda Bicalho, M. de Fátima Gouvea (Orgs.), O Antigo Regime nos trópicos: a dinâmica imperial portuguesa, Rio de Janeiro, Civilização Brasileira, 2001. José Jobson de Andrade Arruda, "Frotas de 1749: um balanço", Revista Vária História, Belo Horizonte, UFMG, $\mathrm{n}^{\circ} 21,1999$, pp. 190-205. (volume especial dedicado ao Códice Costa Matoso).

(24) Lígia Osório Silva. Terras devolutas e latifúndio: efeitos da lei de 1850, Campinas, Editora da Unicamp, 1996, p. 65.

(25) Sobre o processo de extinção das capitanias donatárias, ver Antonio Vasconcelos de Saldanha, As capitanias do Brasil: antecedentes, desenvolvimento e extinção de um fenômeno atlântico, Lisboa, CNCDP, 2001, pp. 387-440. Sobre as reformas pombalinas, ver: Francisco Falcon, A época pombalina, São Paulo, Ática, pp. 412-415. Sobre a expansão das vilas: Maria Helena Ochi Flexor. "Criação da rede urbana na Capitania da Bahia: século XVIII", Universo Urbanistico Português, CNCDP, 2000, pp. 533-553; Claudia Damasceno Fonseca, "As vilas e os territórios: processo de formação e evolução da rede urbana na capitania de Minas Gerais", pp. 769-785; Renata Araújo, "A fronteira a ocidente: o Mato Grosso", Universo Urbanístico Português, CNCDP, 2000, pp. 887-903; Beatriz Bueno, Desenho e Desígnio: O Brasil dos Engenheiros Militares (1500-1822). São Paulo, tese de doutorado FAU-USP, 2001. 
Academia Brasílica dos Renascidos, nessa conjuntura, tomava para si a tarefa de construir a memória histórica de 250 anos de colonização na América. Os membros pertencentes aos quadros da Academia conformavam uma ampla rede de diversas naturezas - familiares, comerciais, burocráticas e eclesiásticas - apontando, nessa medida, o adensamento dos contatos entre as diferentes capitanias já em meados do século XVIII. As rotas de peregrinação das mercadorias, mão-de-obra e informações esboçavam uma territorialidade nem sempre compatível com o desenho da administração metropolitana ${ }^{(26)}$. De fato, o programa proposto pelos renascidos não coincidia com a hierarquia político-administrativa estabelecida pela Coroa após a suspensão do regime de donatárias em 1759 , como veremos a seguir.

Em seus empenhos eruditos, os acadêmicos vislumbravam a preeminência dos interesses da capital administrativa do Estado do Brasil (Salvador), procurando restringir a jurisdição (pelo menos do ponto de vista historiográfico) de Gomes Freire de Andrade, governador geral das capitanias do Rio de Janeiro, Minas Gerais, São Paulo, Colônia do Sacramento, Mato Grosso e Goiás (comparar o mapa 1 e 2). O programa historiográfico dos Renascidos permite confrontar a territorialidade instituída pela Coroa com o processo de ocupação efetiva do território. Com efeito, os acadêmicos planejaram dividir a América portuguesa em cinco macro-regiões:

1) formada pelo Estado do Grão-Pará e Maranhão abarcando as donatárias incorporadas pela Coroa em 1753-4 (Cahité, Camutá, Cumá, Ilha Grande de Joanes) e a capitania do Rio Negro;

2) uma outra região formada por uma área que poderíamos chamar de "grande Bahia", compreendendo a capitania geral da Bahia, comarca de Sergipe, capitania do Piauí, capitania de Goiás, comarca do Serro Frio, capitanias de Ilhéus, Porto Seguro e Espírito Santo.

3) a capitania geral de Pernambuco (compreendendo as capitanias donatárias que estavam em negociação com a Coroa (Itamaraca, Serinhahem, Porto Calvo e Alagoas) e as capitanias do Ceará, Rio Grande do Norte e Paraíba;

(26) Sobre a concepção de territorialidade: Antônio Carlos Robert de Moraes, Bases da formação territorial do Brasil, São Paulo, Hucitec, 2000. 
4) Rio de Janeiro (englobando, além das donatárias (Cabo Frio, Goitacazes, São Vicente), as capitanias de São Paulo e de Santa Catarina, anexadas durante o governo de Gomes Freire de Andrade, entre 1748 e 1763); e, finalmente,

5) as capitanias reais recém-criadas da região Sul, que eram subalternas ao governo do Rio de Janeiro e abrangiam as áreas em litígio e demarcação fronteiriça, como a Colônia do Sacramento, a Banda Oriental do Uruguai, Rio Grande do Sul e Mato Grosso.

A divisão sugerida expressa a formulação de um modelo alternativo de regionalização e hierarquização das diferentes regiões, o qual contraditava a distinção oficial entre capitanias gerais e subalternas ${ }^{(27)}$. Vejamos alguns exemplos que ilustram essa percepção de uma territorialidade centrada nos interesses das elites enraizadas na "grande Bahia", conforme definiu o historiador Felisbello Freire ${ }^{(28)}$. A capitania de Goiás - subalterna à capitania-geral do Rio de Janeiro - deveria, do ponto de vista dos estudos acadêmicos, formar uma unidade com a capitania de São José do Rio Negro (instituída em 1755) ${ }^{(29)}$. Contudo, a capitania do Rio Negro estava sob jurisdição do Estado do Grão-Pará e Maranhão e, por isso mesmo, subordinava-se ao Tribunal da Relação de Lisboa, enquanto os processos e demandas relativas à capitania de Goiás deveriam seguir pelas alçadas do Tribunal da Relação do Rio de Janeiro. O Mato Grosso formava com Goiás e São José do Rio Negro uma importante via de comunicação com as capitanias do Norte a partir de rotas de abastecimento, tráfico e escoamento clandestino do ouro ${ }^{(30)}$.

(27) Paulo Pedro Péricles, "A organização político-administrativa e o processo de regionalização do território colonial brasileiro", Revista do Departamento de Geografia, nº 9, pp. 77-89, 1995; Caio Prado Jr., Formação do Brasil contemporâneo, São Paulo, Brasiliense, 1953, pp. 303-304.

(28) Felisbello Freire, História territorial do Brazil, Rio de Janeiro, tip. Jornal do Comercio, 1906. Agradeço a Mônica Dantas a sugestão de leitura.

(29) Mary Karasch, Goiás (verbete); Maria Beatriz Nizza da Silva (org.), Dicionário da história da colonização portuguesa no Brasil, Lisboa, São Paulo, Verbo, 1994, p. 370.

(30) Francisco Jorge dos Santos, Além da conquista: guerras e rebeliões indígenas na Amazônia pombalina, Manaus, Editora da Universidade do Amazonas, 1999. pp. 11-43. 
Enfim, as jurisdições não coincidiam com os fluxos internos de mercadorias, pessoas e informações, e os acadêmicos procuraram redesenhar a territorialidade a partir de sua própria experiência.

Os eruditos brasílicos propunham deslocar a capitania do Mato Grosso para o bloco de capitanias sulinas formadas pelas praças do Rio Grande de São Pedro, Colônia do Sacramento e Banda Oriental do Uruguai, conferindo, assim, uma certa unidade estratégica às regiões de fronteira litigiosa. O afastamento de Goiás e Mato Grosso da órbita de influência do governo do Rio de Janeiro configura uma intenção de quebrar a primazia político-militar do governador geral Gomes Freire de Andrade - responsável pelas comissões de demarcação do Tratado de Madri - fruto de um ressentimento local que se acentuaria ainda mais após a transferência da capital do vice-reino do Estado do Brasil de Salvador para o Rio de Janeiro, concretizada em 1763.

O programa historiográfico também sugeria que a capitania de Minas Gerais fosse partida em duas, formando duas regióes autônomas. A comarca do Serro Frio e Minas Novas de Araçuaí conformaria uma primeira região, e uma segunda corresponderia à área de jurisdição do bispado de Mariana, formada pelas vilas de Ouro Preto, Sabará, São João del Rei e a cidade de Mariana. Serro Frio e Minas Novas de Araçuaí constituíam uma região sob nítida influência da "grande Bahia" e, por isso mesmo, mereceriam um estudo individualizado. Entretanto, vale destacar que a incorporação do território de Minas Novas de Araçuaí à administração da capitania de Minas Gerais (e, portanto, sob jurisdição do Tribunal da Relação do Rio de Janeiro) era recente, datando de 1757. Contudo, sob o ponto de vista da administração eclesiástica, essa região continuaria sob controle direto do Arcebispado da Bahia, constituindo um foco de conflitos de competência ao longo de todo o século XVIII ${ }^{(31)}$. A região do sudoeste da Bahia e norte de Minas tinha sido ocupada na transição do século XVII para o XVIII por duas correntes de povoamento - uma baiana e outra paulista. Em meados do século XVIII, os colonos ali estabelecidos

(31) Decreto de 11 de maio de 1757. Ignacio Acciolli de Cerqueira e Silva. Memórias Históricas e Políticas da Província da Bahia, ob. cit., p. 203; Andrea Lisly Gonçalves, Catequese, côngruas e jurisdição religiosa no Termo de Minas Novas do Araçuai, relatório de pesquisa do Projeto Berilo Vivo, coordenado pela Pró-Reitoria de Extensão da UFOP, 2001 (exemplar cedido pela autora). 
reivindicavam a regularização de suas posses úteis aos herdeiros da família Guedes de Brito. Estes últimos, por sua vez, alegavam ter recebido sesmarias continentais naquelas partes ${ }^{(32)}$. Os acadêmicos João Calmon (1668-1737), Pedro Leolino Mariz e Romão Gramacho Falcão, por exemplo, eram foreiros dos Guedes de Brito e pertenciam à sua rede clientelar, que se estendia do norte de Minas até o Piauí.

Nessa perspectiva, deve-se considerar a possibilidade de que as memórias genealógicas preparadas pelos acadêmicos renascidos (a exemplo de Frei Antônio de Santa Maria Jaboatão ou de Antônio José Vitoriano Borges da Fonseca) tenham sido estimuladas por um pipocar de pleitos territoriais provocados pelas sucessivas tentativas de regulamentação das sesmarias "continentais" e, sobretudo, pelas iniciativas metropolitanas de demarcação das sesmarias indígenas, conforme definiam as diretrizes do Diretório dos Indios ${ }^{(33)}$. Da mesma forma, a partir de 1766, medidas pombalinas relacionadas com as leis de sucessão, heranças e legados pios mobilizaram os clãs tradicionais à comprovação de suas propriedades e à defesa de seus privilégios de instituir vínculos de morgados e capelas ${ }^{(34)}$. Estava em curso o processo de desamortização e desvinculação dos bens eclesiásticos, cuja expressão legal viria a se cristalizar com a decretação da lei da Boa Razão em 1769. Desde então, o novo sistema de fontes legais do direito pátrio português desautorizava as práticas costumeiras de ocupação fundiária, revogando toda legislação

(32) Erivaldo Fagundes Neves, Da sesmaria ao minifúndio: uma comunidade sertaneja. Salvador, Edufba, 1998, pp. 65/91/101; Monica Duarte Dantas, "Povoamento e ocupação do sertão de dentro baiano: Itapecuru 1549-1822", Penélope, Oeiras, $n^{\circ}$ 23, pp. 9-30, 2000; Rui Lourido, "A Princesa do Sertão: documentos para a história do Recôncavo Baiano e de Feira de Santana", 2001 (exemplar cedido pelo autor).

(33) Maria Helena Ochi Flexor, "Criação da rede urbana na Capitania da Bahia: século XVIII", Universo Urbanistico Português, CNCDP, 2000; Erivaldo Fagundes Neves, "Sesmarias em Portugal e no Brasil", Politeia, Vitória da Conquista, vol. 1, no 1, pp. 111-139, 2001.

(34) Ana Cristina Araújo, A morte em Lisboa, Lisboa, Notícias Editorial, 1997, pp. 273-280; Laurinda Abreu, "Algumas considerações sobre vínculos", Revista Portuguesa de História, Coimbra, tomo XXXV, 2001-2, pp. 335-346; Maria Beatriz Nizza da Silva, "Herança no Brasil colonial: os bens vinculados", Revista de Ciências Históricas, Lisboa, vol. 5, 1990, pp. 291-319. 
com menos de 100 anos de vigência ${ }^{(35)}$. No entanto, é importante levar em conta que a indefinição dos limites da propriedade fundiária era parte constitutiva da dinâmica que movia o avanço das frentes de povoamento e ocupação colonial ${ }^{(36)}$. Com efeito, a infixidez das fronteiras territoriais ou a falta de delimitação da propriedade permitia a reprodução social das elites luso-americanas. As circunstâncias impeliam à necessidade de fixar uma memória histórica da ocupação e povoamento do território, com vistas a assegurar os títulos de propriedade das sesmarias concedidas, como, também, a preservar os privilégios estamentais daqueles segmentos sociais ${ }^{(37)}$. Portanto, as memórias e catálogos genealógicos escritos durante a segunda metade do século XVIII revelam uma estratégia de sedimentação social das linhagens familiares mais antigas, visando, sobretudo, à manutenção das prerrogativas e dos dividendos adquiridos por intermédio dos serviços prestados pelos vassalos à Coroa $^{(38)}$. Tais benefícios eram consubstanciados por meio da concessão

(35) A lei da Boa Razão alterou o sistema de fontes e impôs o abandono do direito romano, retirando a legitimidade dos costumes (com menos de 100 anos) que pudessem revogar as leis (instituto do dessuetudo) ou que fossem contra o direito pátrio. A lei da Boa Razão foi decretada em 18 de agosto. Auxiliar Jurídico. Apêndice às Ordenações Filipinas, edição de Candido Mendes de Almeida, Lisboa, Fundação Gulbenkian, 1985.

(36) José Reinaldo Lima Lopes sugere, porém, que no Brasil os julgamentos dependiam necessariamente dos arranjos costumeiros, de modo que a legislação relativa à sesmaria, por exemplo, teria sido extraordinária. Caberia indagar: se a passagem da Monarquia Corporativa para a nova ordem estatal (legalista) teve efeitos divergentes no Reino e no Ultramar (onde a fronteira aberta condicionava o modelo de povoamento colonial). José Reinaldo de Lima Lopes, $O$ Direito na História, São Paulo, Max Limonad, 2000, pp. 270-271; Arno Wehling, "A Bahia no contexto da administração ilustrada. 1750-1808", Anais do IV Congresso de História da Bahia, Salvador, 2001; Antonio Manuel Hespanha, "O Jurista e o legislador na construção da propriedade burguesa liberal em Portugal", Análise Social, volume XVII (61-62), 1980, pp. 211-236.

(37) Wanderley Pinho. História de um engenho do Recôncavo, São Paulo, Cia Editora Nacional, 1982, p. 451; Diogo Ramada Curto, "Notes à propos de la nobiliarquia paulistana de Pedro Taques", Arquivo do Centro Cultural Calouste Gulbenkian, vol. XXXIX, Fundação Calouste Gulbenkian, 2001, pp. 109-118.

${ }^{(38)}$ Katia Maria Abud, O sangue intimorado e as nobilissimas tradições ( $A$ construf̧ão de um símbolo paulista: o bandeirante), Doutorado, São Paulo, FFLCH-USP, 1985. 
de comendas, hábitos, patentes militares, designação de ofícios públicos, atribuição de sesmarias, entre outros privilégios ${ }^{(39)}$. Assim, os genealogistas brasílicos recorriam à retórica de exaltação das virtudes nobiliárquicas das principais familias americanas, registrando suas prerrogativas imemoriais no âmbito do regime de remuneração de mercês, uma prática que, aliás, constituía um importante pilar de estruturação e legitimação dos poderes imperiais no ultramar ${ }^{(40)}$. Não obstante, as reformas da administração pública caminhavam no sentido de alterar os pressupostos da "economia política das mercês".

A comissão de conselheiros ultramarinos liderada por José Mascarenhas, por exemplo, tinha a importante tarefa de fazer a avaliação dos rendimentos dos ofícios públicos com o objetivo de transferi-los em propriedade vitalícia e hereditária por arrematação às maiores ofertas ${ }^{(41)}$. A venda direta dos títulos de propriedade dos ofícios e dos cargos de serventuários excluía a possibilidade de que os titulares sublocassem a exploração dos ofícios e cargos de serventuários a terceiros, como era o costume. Dessa forma, a Coroa tentava maximizar os seus rendimentos e, ao mesmo tempo, coibir a formação das clientelas em torno dos titulares, desestruturando, assim, as hierarquias e cadeias de dependência localmente enraizadas. Neste caso, a resistência dos baianos foi imediata e impediu a implementação do novo sistema de arrematação(42).

(39) Antônio Manuel Hespanha, "La Economia política de la Graça", in La gracia del derecho, Madrid, Centro de Estudios Constitucionales, 1993. Veja-se para o exemplo da América portuguesa a coletânea organizada por João Fragoso, Maria Fernanda Bicalho e Maria de Fátima Gouvea, O Antigo Regime nos trópicos: a dinâmica imperial portuguesa, Rio de Janeiro, Civilização Brasileira, 2001.

(40) Maria Fernanda de Olival, As Ordens Militares e o Estado Moderno: Honra, mercê e venalidade: em Portugal (1641-1789), Lisboa, Estar, 2001; Francisco Bethencourt (Dir.), História da expansão portuguesa, Lisboa, Temas e Debates, 1998, vol. 3, pp. 294-388.

(41) "Ofício do conselheiro Antônio de Azevedo Coutinho ao secretário de Estado Sebastião José de Carvalho e Melo comunicando a chegada à Bahia da comissão especial para erigir Tribunal de Consciência e Ordem", AHU-ACL-CU-005, cx. 137, d. 10607, 18/9/1758.

(42) Alberto Gallo, La venalidad de oficios públicos en Brasil durante el siglo XVIII, in Marco Berllingeri (Coord.), Dinámicas de antiguo régimen y orden constitucional: representación, justicia y administración en iberoamérica siglos XVIII-XIX, Torino, Otto Editore, 2000. Agradeço Helen Osório pela indicação do artigo. 
Os acadêmicos alimentavam a expectativa de que a criação da Academia Brasílica dos Renascidos pudesse ter algum impacto na conservação do regime tradicional de remuneração de mercês. Se as descrições geográficas, relações panegíricas e memórias históricas constituíam uma documentação comprobatória nas demandas de remuneração pelos serviços régios, a tendência de racionalização da administração pública obrigava à transformação das regras de reciprocidade, até então consagrada pela tópica: "sangue, vidas e fazenda"(43). Os acadêmicos não pretendiam questionar a lealdade imperial, mas, ao contrário, justificavam a empresa acadêmica em nome dos "progressos a honra da Pátria e a gloria dos doutos Portugueses Americanos"(44). Se, por um lado, a existência de uma academia lusoamericana promovia a afirmação da soberania portuguesa na América (conforme vislumbrou José Mascarenhas), por outro, ela também abria uma via de autonomização dos interesses luso-americanos e, por isso mesmo, podia significar uma ameaça à soberania portuguesa num contexto de intensificação das disputas inter-metropolitanas deflagrado pela Guerra dos Sete Anos (1756-63).

Os Renascidos se dispunham ao desafio de pensar o espaço americano como uma unidade geopolítica e econômica: um território indivisível e homogêneo, dotado de um passado particular, mas inserido na temporalidade da história da cristandade universal. O programa de estudos transcendia os localismos e as divisões administrativas oficiais. Com efeito, em meados do século XVIII, as diferentes redes que constituíam esse arquipélago de territórios, aparentemente descontínuos do ponto de vista da uniformidade administrativa, já traduziam articulações econômicas e sociais de alcance regional e macrorregional ${ }^{(45)}$. Nessa perspectiva, a fluidez das delimitações das circunscrições judiciárias, eclesiásticas e militares demandava o estabelecimento de pactos

(43) Evaldo Cabral de Mello, Rubro Veio: o imaginário da restauração pernambucana. Rio de Janeiro, Nova Fronteira, 1986; Cleonir Xavier de Albuquerque, A remuneração de serviços da guerra holandesa, Recife, UFPE, Imprensa Universitária, 1968.

(44) BNL, Fundo Geral. Ms cod. 630. Estatutos da Academia Brasílica dos Renascidos, fls. 236-250.

(45) István Jancsó e João Paulo Pimenta, Peças de mosaico: cinco estudos sobre a formação política do Brasil, textos de livre docência, Universidade de São Paulo, 2001; Demétrio Magnoli, "O Estado em busco do seu território", in Istvan Jancso, Brasil: Formação do Estado e da Nação, São Paulo, Hucitec, 2003, pp. 285-296. 
intra-elites, acordos que contemplassem políticas de fixação e controle das populações pobres trabalhadoras situadas nos enclaves quilombolas e indígenas.

Embora tenha aberto um canal de negociação junto às elites locais, a simples existência de uma academia com vocação historiográfica representava um fator de estímulo à autonomização intelectual dos colonos, desde que ela propiciava a formação de uma percepção mais global da realidade colonial (decorrente da circulação de informações entre acadêmicos de diferentes regiões) e aumentando, assim, as possibilidades de superação da fragmentação política imposta pela administração metropolitana. Mesmo que, em tese, a proposta de escrever uma história continental convergisse com os interesses geopolíticos metropolitanos, os acadêmicos baianos propunham um arranjo de organização do território alternativo, que lhes permitisse recuperar a centralidade perdida com o deslocamento do eixo econômico e político para a região centro-sul.

\section{As redes ultramarinas e o cosmopolitismo erudito lusoamericano}

José Mascarenhas Pacheco Pereira Coelho de Melo tinha fortes laços com o mundo americano. Seu pai, o desembargador João Pacheco Pereira Coelho de Melo, era natural da cidade de Salvador e tinha ocupado importantes cargos na magistratura americana e reinol. Entre os postos que exerceu na América destacam-se os de ouvidor geral da comarca de Ouro Preto (1724) e o prestigioso lugar de chanceler do recém-criado Tribunal da Relação do Rio de Janeiro (1752). Em 1757, seu pai tinha sido o responsável pela violenta repressão à revolta popular contra a Companhia das Vinhas do Douro na cidade do Porto, contando, nessa ocasião, com a assistência do próprio José Mascarenhas (como escrivão da devassa). Todavia, o cursus honorum de João Pacheco Pereira Coelho de Melo não teria sido suficiente para legar uma herança abastada a seu filho, que chegou a requerer à Coroa a remuneração de suas mercês pelos serviços prestados pelo pai no Ultramar ${ }^{(46)}$.

(46) ANTT. Registro Geral de Testamentos, livro 327, fl. 205v/208. Agradeço a Tiago C. P. dos Reis Miranda a indicação do testamento. 
Aos 38 anos, José Mascarenhas tinha credenciais suficientes para que Pombal o elegesse como condutor da política de expulsão e confisco do patrimônio dos jesuítas. Reconhecido no mundo acadêmico europeu, o desembargador e conselheiro ultramarino tinha sido aceito como sócio correspondente da Real Academia de la Historia e da Academia de Geografia de Valladolid na Espanha. Em Portugal, seu campo de relacionamentos também era significativo. Além de integrar o quadro de membros numerários da Academia Real de História Portuguesa, ele tinha sido eleito presidente da Academia dos Ocultos de Lisboa (1745-1751) e integrava os quadros da Academia Litúrgica Pontifícia de Coimbra (1758-1762), patrocinada pela Santa Sé(47).

Ao tomar as primeiras providências para a criação da Academia, o enviado especial de Pombal procurou recrutar os principais segmentos da elite local. De modo que o cargo de secretário geral da Academia foi atribuído a Antônio Gomes Ferrão Castelo Branco, descendente de uma importante família na Bahia, com ramificações em Pernambuco, Minas e São Paulo e negócios que se estendiam pela África e pelo Reino. A difícil conjuntura de estagnação dos engenhos de açúcar transformava os postos das milícias numa forma de preservação do prestígio social ${ }^{(48)}$. No início

(47) BGUC Mss. 455. José Mascarenhas Pacheco Pereira Coelho de Melo: "Oração gratulatória que disse - sendo eleito Acadêmico da Real Academia", fls. 193-199; "Oração gratulatória que disse: sendo eleito Acadêmico do numero na Academia, como presidente da academia dos ocultos na conferencia de 14 de outubro de $1755 "$ " fl. 200-204.

${ }^{(48)}$ Castelo Branco contava 31 anos, mas já reunia suficientes qualidades para assumir os encargos de uma secretaria acadêmica, inclusive a fluência na língua francesa. Era bisneto de Pedro Unhão Castelo Branco, influente desembargador português que se brasilianizou na Bahia; seu avô (Antônio Gomes Ferrão) tinha sido mestre-de-campo geral da Praça da Bahia seu pai (Alexandre Gomes Ferrão) ocupara cargos, entre os quais o de provedor da Santa Casa de Misericórdia e vereador na Câmara de Salvador. Pela via materna, era neto do sertanista paulista Salvador Cardoso de Oliveira - casado com uma descendente da Casa da Torre (Maria da Cruz Porto Carrero) -, estabelecido com fazendas de gado no Rio das Velhas. Antônio Gomes Ferrão Castelo Branco empenhou-se na instituição do morgado do Porto da Folha, que estava ameaçado de ser perdido. Biblioteca José Mindlin. Ms. Borrador de Antônio Gomes Ferrão Castelo Branco, ob. cit., fl. 37v. As informações sobre os negócios da família constam do diário pessoal de Antônio Gomes Ferrão, a documentação original faz parte do acervo da Biblioteca José Mindlin (SP-Brasil), manuscrito original transcrito por Rosana 
da década de 1750, Antônio Gomes Ferrão Castelo Branco lutava para reerguer as finanças da família e legalizar a situação das propriedades no sertão (os morgados do Porto da Folha e do Padre Eterno). A Familia Gomes Ferrão Castelo Branco estava empenhada com diversas casas de crédito na cidade, devendo a parentes e amigos grandes somas de dinheiro. O secretário da Academia era também ligado ao poderoso contratador de tabaco Joaquim Inácio da Cruz, um dos prováveis financiadores do empreendimento acadêmico ${ }^{(49)}$.

A familia Gomes Ferrão apresentava uma densa rede de relações familiares, indicativa do processo de formação dos primeiros clãs coloniais e da sedimentação social, tanto dos laços inter-regionais, como dos ultramarinos. $\mathrm{O}$ mesmo perfil apresentavam outros membros destacados da Academia dos Renascidos, como Rodrigo da Costa e Almeida (neto de Sebastião da Rocha Pita) ${ }^{(50)}$ e José Pires de Carvalho e Albuquerque (1709-1770) ${ }^{(51)}$. Todos eram membros de famílias de antiga fixação na Bahia, com três gerações de fidalgos da Casa Real, professos na Ordem de Cristo e familiares do Santo Ofício. O processo de arregimentação social dos acadêmicos renascidos abrangia de laços familiares até experiências socializadoras compartilhadas na Universidade de Coimbra e nas diferentes partes do Império português. Além das famílias de antigos senhores de engenho e fazendas de gado, entre os membros do corpo acadêmico brasílico é preciso destacar a presença de grandes

Gonçalves; veja-se o artigo Mary del Priore, "Deus ou Diabo nas Terras do Açúcar: o senhor de engenho na América portuguesa", in Mary del Priore (org), Revisão do Paraíso, Campinas, Editora Campus, 2000, pp. 15-44/34-35. Agradeço ao Dr. José Mindlin, Dra. Mary del Priore e Rosana Gonçalves pelo acesso à transcrição do Borrador.

(49) Iris Kantor, De Esquecidos e Renascidos: a historiografia acadêmica luso-americana, doutorado, Universidade de São Paulo, 2002.

(50) Pedro Calmon, "Prefácio", in Sebastião da Rocha Pita, História da América Portuguesa, Belo Horizonte, Itatiaia, 1976, p. 17. Casado com sua irmã Isabel Joaquina de Aragão.

(51) Seu sobrinho, homônimo, filho do seu irmão Salvador Pires de Albuquerque Carvalho, casou-se com Leonor Pereira Marinho, herdando o morgado da Casa da Torre. Alberto Moniz Bandeira, O feudo: a Casa da Torre de Garcia d'Avilla - da conquista dos sertões à independência do Brasil. Rio de Janeiro, Civilização Brasileira, 1999. 
negociantes de tabaco e escravos, dos homens ligados às carreiras da magistratura e às funções eclesiásticas e administrativas ${ }^{(52)}$.

A distribuição geográfica dos acadêmicos demonstra uma ampla rede de contatos que transcendia à esfera local, com abrangência continental e inter-continental. Por definição dos Estatutos, os acadêmicos residentes na Europa deveriam enviar suas respectivas dissertações ao menos uma vez por ano. Recomendava-se também constância na comunicação dos estudos entre os sócios. Dos acadêmicos americanos exigia-se a periodicidade mínima de três meses, para não correrem o risco de serem "riscados" da instituição. Diversos supranumerários estrangeiros seriam incumbidos de remeter suas memórias conforme uma agenda de trabalhos anual elaborada pela mesa censória.

No Reino, a rede de supranumerários contava com correspondentes em Lisboa, Coimbra, Porto, Miranda e Montemor-o-Velho. Muitos deles compunham ou vieram a compor a cúpula do reformismo pombalino, como é o caso dos supranumerários brasílicos João Pereira Ramos de Azeredo Coutinho (1722-?), José Seabra da Silva (1732-1813) e Manoel do Cenáculo Vilas Boas (1724-1814). João Pereira Ramos de Azeredo Coutinho, por exemplo, era natural da cidade do Rio de Janeiro, mas tinha ascendentes provenientes do Porto e do Faial (Açores), estabelecidos havia duas gerações na cidade do Rio de Janeiro. Filho primogênito de uma rica família de senhores de engenho e fazendas de gado e cavalo, era herdeiro do morgado de Marapicú, na capitania do Rio de Janeiro ${ }^{(53)}$, e irmão do reformador da Universidade de Coimbra, Francisco de Lemos de Faria Pereira Coutinho de Melo, e do capitão dos Dragões da capitania do Piauí, Clemente Pereira de Azeredo Coutinho de Melo. A familia Pereira Ramos de Azeredo Coutinho reconstituía sua linhagem a partir do primeiro donatário da capitania do Espírito Santo, Vasco Fernandes Coutinho (1534), passando pelo seu trisavô, João Mateus

(52) Na segunda parte do trabalho procurei reconstituir os perfis sociais dos acadêmicos renascidos. Iris Kantor, De Esquecidos e Renascidos: a historiografia acadêmica luso-americana, ob. cit.

(53) O morgado foi instituído em 1772 e incluía os engenhos de Marapicú e Cabaçú, as fazendas de Paul do Guandu e Itaúna, os criatórios de Passos no Rio de Janeiro. Maria Beatriz Nizza da Silva, "Herança no Brasil colonial: os bens vinculados", ob. cit., pp. 291-319, 1990. 
Rendon, até o seu tataravô, Amador Bueno da Ribeira ${ }^{(54)}$. Além das memórias genealógicas da América portuguesa, os acadêmicos renascidos tinham incumbido João Pereira de escrever as memórias do Bispado de Mariana.

Tendo construído uma carreira exemplar durante o período pombalino, sobrevivendo após a Viradeira (1777) com o mesmo desempenho, João Pereira Ramos de Azeredo Coutinho era homem a serviço da Coroa. Ocupou cargos de grande prestígio, atuou como censor na Real Mesa Censória (1768), assistiu seu irmão no processo de reforma da Universidade de Coimbra (1772), participou do processo de implantação do Erário Régio e preparou a Concordata de 1774. Em 1789, foi agraciado com o cargo de conservador geral e executor do tabaco e, já ao final de sua carreira, foi eleito ministro na Junta do Exame do Estado e Melhoramento Temporal das Ordens Regulares em 1790(55).

O magistrado José Seabra da Silva, outro membro da elite pombalina pertencente aos quadros supranumerários dos acadêmicos renascidos, atuou, em 1757, como fiscal da Companhia Geral do Grão-Pará e Maranhão e, em 1759, ocupou o cargo de procurador-geral da Coroa, acumulando os lugares de desembargador do Paço e juiz da Bula da Cruzada $^{(56)}$. Em 1771, foi nomeado ministro de Estado, atingindo o ponto culminante de sua carreira, para em seguida, em 1774, cair em desgraça, sendo encarcerado por Pombal na Ilha das Cobras (Rio de Janeiro) e no presídio das Pedras Negras em Pungo Andongo (Angola), onde permaneceu até $o$ indulto da Viradeira ${ }^{(57)}$. José Seabra da Silva era casado com uma descendente de Francisco Pereira Coutinho, primeiro donatário

(54) ANTT. Habilitação do Santo Ofício, letra J, mç. 93, doc. 1588 (1750). Frei Gaspar da Madre de Deus, Memórias para a História da Capitania de S. Vicente, hoje chamada São Paulo, item 184, p. 142, edição Martins, 1922,

(55) Januário da Cunha Barbosa, "João Pereira Ramos de Azeredo Coutinho", Revista do Instituto Histórico e Geográfico Brasileiro, tomo 2, Rio de Janeiro, 1858, pp. 118-126.

(56) ANTT. Registro Geral de Mercês. D. José I, liv. 12, 23.

(57) Segundo uma memória manuscrita dedicada ao reinado de D. José, José Seabra da Silva foi um dos responsáveis pela reorganização do Arquivo da Torre do Tombo, sendo responsável pela preparação das notícias das doações e mercês régias. Biblioteca José Mindlin. Ms. História política econômica do reinado de S. Magestade D. José I. 
da Capitania da Bahia de Todos os Santos ${ }^{(58)}$. João Pereira Ramos de Azeredo Coutinho e José Seabra da Silva foram responsáveis pela preparação da Dedução Cronológica (1768), que viria a constituir o principal arrazoado jurídico na campanha contra a Companhia de Jesus. Ambos foram nomeados guardas-mores da Torre do Tombo (Seabra da Silva em 1768 e Azevedo Coutinho entre 1774 e 1799)(59). João Pereira Ramos de Azeredo Coutinho foi o testamenteiro de José Mascarenhas em 1789, e Seabra da Silva, conforme ficou registrado no testamento, foi seu "maior e o melhor amigo"(60).

A rede de contatos do principal articulador da Academia dos Renascidos, José Mascarenhas, envolvia relações familiares, vivências comuns compartilhadas nos bancos da universidade e experiência em cargos da administração pública. Mascarenhas e seus amigos próximos, como José Seabra da Silva e João Pereira Ramos de Azeredo Coutinho, faziam parte das novas elites recrutadas pelo consulado pombalino, compondo os quadros da "nobreza de serviço" imperial ${ }^{(61)}$.

Ao contrário do que ocorria nas demais academias formadas no período colonial (tais como as academias dos Esquecidos, dos Felizes ou dos Seletos), os Renascidos pretendiam estabelecer intercâmbio com instituições portuguesas e européias, contando para tanto com a presença de diretores e membros destacados de diversas academias, tais como: a Academia Real de História Portuguesa, a Academia dos Ocultos, a Litúrgica Pontifícia de Coimbra, a Arcádia Lusitana e a Academia Portopolitana, a Academia Real de la Historia na Espanha e a Academia de Geografia de Valladolid.

O conselheiro ultramarino Pedro José da Silva Botelho, membro censor da Academia Real de História Portuguesa ${ }^{(62)}$, foi convidado para

(58) Henrique Campos Simões, As Cartas do Brasil, Ilhéus, Editus, 1999, pp. 39-41.

(59) Fernanda Ribeiro, O acesso à informação nos arquivos, tese (doutoramento), Universidade do Porto, 1998.

${ }^{\left({ }^{60}\right)}$ ANTT. Registro Geral de Testamentos, livro 327, fl. 205v/208.

(61) Nuno Gonçalo Monteiro, "Trajetórias sociais e governo das conquistas: notas preliminares sobre os vice-reis e governadores do Brasil e da Índia nos séculos XVII e XVIII", in O Antigo Regime nos trópicos, ob. cit., pp. 249-283.

${ }^{(62)}$ Sobre a Academia Real de História Portuguesa veja-se o trabalho de Isabel Ferreira da Mota, A Academia Real da História. A história e os historiadores na primeira metade do séc. XVIII, Coimbra, Doutorado, Universidade de Coimbra, 2001; ANTT Mesa de Consciência e Ordens. Mss. Actas da Academia Real, 1761. 
participar da Academia Brasílica dos Renascidos, com a incumbência de apresentar uma "coleção de todas as leis e ordens régias expedidas para América desde o seu descobrimento até o presente com as notas que parecem convenientes para sua melhor inteligência"(63). A iniciativa de organizar o corpo da legislação referente aos domínios americanos partia dos Renascidos, mas não podia descartar a colaboração dos sócios supranumerários lisboetas em posição de comando na administração ultramarina. Desde que não havia uma legislação específica para a América portuguesa, os acadêmicos julgaram oportuna a iniciativa de organizar a jurisprudência americana.

Entre os membros reinóis convidados a apresentar uma memória sobre a história natural, encontrava-se o diretor da Academia Portopolitana, o médico Manoel Gomes de Lima (1727-1806). A Academia portuense, fundada em 1749 (sob proteção do arcebispo de Braga, D. José de Bragança) e dedicada ao cultivo da medicina experimental, mantinha estreitos contatos com suas congêneres européias, especialmente em Sevilha, Madri, Paris, Lyon, Leiden, Veneza, Amsterdam e Londres ${ }^{(64)}$. Os Renascidos contavam também com membros numerários da Real Academia de la Historia, entre eles o diretor, Augustin Montiano y Loyando; o bibliotecário-mor da real biblioteca pública, Juan Santander y Zorillla; o presidente do conselho de Estado, Fernando Velasco e o administrador das rendas de ofícios públicos e cargos eclesiásticos da Coroa espanhola, Miguel de Medina y Flores. Este fazia parte da junta censora dedicada aos temas americanistas na Real Academia de la Historia e, na Academia dos Renascidos, tinha sido escalado para apresentar uma dissertação comparando as qualidades intelectuais dos índios do Brasil com as dos índios da América hispânica ${ }^{(65)}$. Aqui, a discussão

(63) BPME. CIX/1-18. Academia Brasílica dos Renascidos (Distribuição de Empregos).

(64) Francisco de las Barras de Aragon, "Relaciones científicas sostenidas entre las academias de Oporto y Sevilha en el siglo XVIII", in Congresso de Oporto, Anais..., Cidade, Jimenez y Molina Impressores, 1921, t. 6, pp. 115-123; António Alberto Banha Andrade, "Uma academia científica luso-espanhola antes da expulsão dos jesuítas", Brotéria, Lisboa, vol. 40, 1945, pp. 619-635.

${ }^{(65)}$ Maria Tereza Nava Rodrigues, Reformismo ilustrado y americanismo: La Real Academia de la Historia (1735-1792), Madrid, Doutorado, Universidad Complutense de Madrid, 1989, p. 541. 
referia-se diretamente às polêmicas sobre a inferioridade natural dos indígenas que habitavam os domínios luso americanos em comparação com os indígenas hipano-americanos. Valendo-se de argumentos etnológicos, os eruditos brasílicos questionavam a aplicação do modelo de "autogoverno" das comunidades indígenas hispano-americanas pretendida pelo Diretório pombalino ${ }^{(6)}$.

Como se pode notar pela significativa presença dos acadêmicos hispânicos, José Mascarenhas mantinha estreitas relações com alguns membros da Real Academia de la Historia, especialmente com o acadêmico Miguel de Medina y Flores, seu amigo particular ${ }^{(67)}$. Em 1754, ele tomava posse na vaga de acadêmico honorário na Real Academia, apresentando pessoalmente sua "oração gratulatória" de admissão(68). Logo após o terramoto de Lisboa (1755), a Academia espanhola encarregou-o de apresentar um informe sobre os danos causados ${ }^{(69)}$. José Mascarenhas havia construído relações de afinidade intelectual com homens profundamente engajados nos projetos de reforma das estruturas estatais, homens comprometidos com fomento da economia nacional, por intermédio da desamortização da propriedade eclesiástica e da promoção de uma nova legislação comercial ultramarina ${ }^{(70)}$.

Após sua eleição para a Real Academia de la Historia em Madri, José Mascarenhas partiu para Valladolid, onde participaria das sessões da recém-fundada Academia de Geografia e Matemática ${ }^{(71)}$. Além dos

(66) Stuart Schwartz/James Lockhart, A América Latina na época colonial, Rio de Janeiro, Civilização Brasileira, 2002, pp. 200-213.

(67) Eva Velasco Moreno, La Real Academia de la Historia en el siglo XVIII: una instituición de sociabilidad. Madrid, Centro de Estudios Políticos e Constitucionales, 2000, p. 159.

(68) “José Mascarenas Pacheco y Pereyra, Oracion gratulatória, que dixo don Joseph de Mascarenas Pacheco y Pereyra quando fue admitido en la Real Academia de la Historia, 3 de outubre, 1754, Madrid, Impresor Gabriel Ramirez". 17p.

(69) ARH. Mss. "Noticia individual que da la Academia de la Historia del terremoto de 1 de noviembre de 1755", leg. 9/5512.

(70) Jean Sarrailh, La España ilustrada de la segunda mitad del siglo XVIII. Trad. Antonio Alatorre. Cidade do México, Fondo de Cultura, 1981; Concepcion de Castro, Campomanes: Estado y reformismo ilustrado, Madrid, Alianza Editorial, 1996.

(71) Marie Hélène Piwnik, Echanges Erudits dans la Peninsule Iberique (1750-1767), Paris/Lisboa, Fondation Calouste Gulbenkian, Centre Culturel Portugais, 1987. Ver capítulo: "Les membres portugais de la Royale Academie d'Histoire de Madrid", p. 122. 
contatos institucionais, ele manteve correspondência durante 17 anos com o jesuíta José Francisco Islã, célebre predicador espanhol, exilado em Bolonha depois da expulsão dos Jesuítas dos domínios espanhóis (1767). Francisco Islã ou Fr. Gerundio de Campazas havia sido acusado de traduzir para o espanhol as notícias da Guerra Guaranítica diretamente extraídas de registros dos comissários da demarcação do Tratado de Madrid ${ }^{(72)}$. As aproximações de José Mascarenhas com as elites intelectuais espanholas criaram desconfiança quanto a sua fidelidade patriótica, o seu trânsito internacional colocava em risco os interesses da Monarquia portuguesa. De fato, naquele momento, a redefinição das fronteiras americanas entre Espanha e Portugal, agravada pela Guerra Guaranítica (1753-6) e pelo processo de expulsão dos jesuítas no Império português (1759), acentuava as contradições entre o princípio do cosmopolitismo intelectual e as implicações políticas do mundo sem fronteiras constituído pelas redes acadêmicas ilustradas. Era justamente nos domínios ultramarinos que as limitações políticas do cospomolitismo ilustrado se apresentavam mais evidentes, dada a ameaça da perda de soberania decorrente da permeabilidade das fronteiras vazadas pela trocas de informação, mercadorias e pessoas.

Quando José Mascarenhas convidou o capitão-tenente da Armada Real Francesa ancorada no porto da Bahia para participar da Academia Brasílica dos Renascidos, o vice-rei D. Marcos de Noronha enviou correspondência ao Conselho Ultramarino criticando a "estreita amizade" entre os dois ${ }^{(73)}$. O vice-rei, que já se havia recusado a emprestar dinheiro da Fazenda Real para o fornecimento da esquadra, denunciava o grande negociante de tabaco Joaquim Inácio da Cruz por ter concedido o empréstimo ao comandante da real esquadra francesa sem sua autorização ${ }^{(74)}$. 1757.

(72) Fr. Gerundio de Campazas, Plan de la nueva republica del Paraguay, Roma,

(73) AHU. "Carta de D. Marcos Noronha de Brito, Bahia, 23, Dezembro, 1759". Documento n. 4430, cx. Baía; cf. Regina Duarte Talhe, A Academia Brasilica dos Renascidos da Baía: sua importância histórico cultural, 2 vol., Universidade Clássica de Lisboa, 1964.

(74) $\mathrm{O}$ vice-rei exigia que o comandante da esquadra francesa fizesse uma petição para que os homens de negócio da praça da Bahia fossem autorizados a fazer o dito empréstimo. Veja-se a carta de Gomes Freire de Andrade, pedindo cautela no tratamento das esquadras francesas: "teve certas evidentes provas de que os franceses, que estiveram nesse porto alojados (no caso no Rio de Janeiro) procu- 
Também acusava José Mascarenhas de colaboracionismo naquela pesada conjuntura de Guerra dos Sete Anos (1756-1763), em que Portugal tinha permanecido aliado da Inglaterra, contra a França e a Espanha (sem aderir ao Pacto de Família em 1761) ${ }^{(75)}$. Embora as alianças franco-portuguesas fossem abertamente impugnadas pelo vice-rei, o capitão-tenente Mrs. Disiers, membro também da Academia de Brest, chegou a receber o título de supranumerário "na forma e no estilo" do protocolo acadêmico dos renascidos.

Cinco meses após a fundação da Academia, José Mascarenhas partia para o Rio de Janeiro, onde foi preso e remetido para o presídio na ilha de Santa Catarina (forte de Santa Cruz de Anhatomerim). Lá permaneceria confinado durante 14 anos, junto com sua criadagem e livraria particular ${ }^{(76)}$. Sobre sua pessoa pairava o estigma de dupla traição: parceria com os franceses aportados na Bahia e uma tentativa de conciliação com os jesuítas ${ }^{(77)}$. A desconfiança era bastante razoável dado o fato de que a Coroa francesa arquitetava em segredo um plano de invasão do Rio de Janeiro, com perspectivas de estabelecer um vice reino francês no Brasil em 1762; solicitando aos seus informantes o envio de mapas e memórias que descrevessem aquelas praças marítimas. Uma instrução de Luís XV determinara que a Armada Real, comandada pelo general d'Estaing, deveria zarpar do porto de Brest (onde também seriam adquiridos os navios). Em sua correspondência, o experiente general d'Estaing comentava ter atuado como espião na colônia portuguesa alguns anos antes ${ }^{(78)}$. Como se pode ver, a eleição do capitão-tenente

raram e conseguiram tirar informações e deixar estabelecidas correspondências nessa Capitania", Eduardo Castro e Almeida, Inventário dos documentos relativos ao Brasil existentes no Archivo da Marinha e Ultramar, Rio de Janeiro, vol. IV, p. 232.

(75) Tiago Costa Pinto dos Reis Miranda, Ervas de ruim qualidade: a expulsão da Cia. de Jesus e a aliança anglo-portuguesa (1750-1763), Dissertação (Mestrado) Depto. de História da Universidade de São Paulo, 1991.

(76) Acompanharam o seu cárcere 8 criados (muitos deles escravos). ANTT Registro Geral de Testamento, livro 321, 205v /208; Henrique Fontes, O conselheiro José Mascarenhas Pacheco Pereira Coelho de Mello, Florianópolis, Livraria Central de Alberto Entres, 1938, p. 38.

(77) João Lúcio de Azevedo, Novas Epanaforas. Estudos de história e literatura. Lisboa, A. M. Teixeira \& C. ${ }^{\text {a }}$ (Filhos), 1932, pp. 236-237.

(78) Sobre os planos de invasão francesa, veja-se Maria Fernanda Bicalho, A cidade e o império: o Rio de Janeiro na dinâmica colonial portuguesa (XVII-XVIII), Rio de Janeiro, Civilização Brasileira, 2003, pp. 69-80. 
Mrs. Disiers (membro da Academia de Brest) para o quadro da Academia dos Renascidos era demasiadamente ameaçadora e, por hipótese, justificava a imediata prisão de José Mascarenhas.

Durante o governo de D. Maria I, a preparação de memórias econômicas e agrícolas seria novamente emulada pela Academia Real de Ciências de Lisboa (1779), mas convém destacar que as memórias remetidas diretamente à Academia Real de Ciências de Lisboa pelos seus sócios correspondentes na América não puderam contar com a mediação de uma academia americana, como tinha sido idealizado pelos acadêmicos renascidos. Se é verdade que a prisão de Mascarenhas pôs fim à ambição historiográfica de dimensão continental, vale a pena observar que, nas décadas seguintes, as obras escritas e publicadas por essa geração dos eruditos brasílicos não deixaram de ostentar o orgulhoso título de "acadêmicos renascidos" estampado em seus frontispícios ${ }^{(79)}$.

A existência de uma academia sediada na América tinha implicações não apenas no plano da soberania externa, mas também atingia a soberania interna (sobretudo no que toca à resistência dos colonos quanto a implementação do Diretório dos Índios). O projeto de escrever uma História Universal da América Portuguesa configurava, assim, um outro horizonte político, no qual a superação dos localismos e a afirmação de uma identidade política universalista podiam até mesmo transcender os marcos da lealdade imperial ${ }^{(80)}$. O mundo erudito da ilustração católica, constituía um circuito aberto e, muitas vezes, paralelo ou contrário aos interesses de Estado da Coroa portuguesa. Possivelmente, esse tenha sido o principal foco de contradições do cosmopolitismo ilustrado lusoamericano num contexto de intensificação da disputa pela América e de guerras intermetropolitanas ${ }^{(81)}$. Por outro lado, as reflexões do beneditino pernambucano Domingos Loreto Couto (transcritas no início desse artigo) nos permitem identificar as tensões que marcaram a vida intelectual nessas partes do Império português. Em seu modo de ver a

(79) Este foi o caso das obras escritas por José Mirrales (1662), Francisco Calmon (1762), Frei Santa Maria de Jaboatão (1768), José Oliveira Serpa (1760) e José Carvalho de Albuquerque e Carvalho (1761).

${ }^{(80)}$ Diogo Ramada Curto, As práticas de escrita, in F. Bethencourt (Dir.), História da expansão portuguesa, Lisboa, Temas e Debates, 1998, vol. 3, pp. 421-462.

(81) Antonello Gerbi, La disputa del Nuevo Mundo: história de una polémica (1750-1900), Cidade do México, Fondo de Cultura, 1982. 
expansão do império requeria o estímulo à autonomização política, social e cultural das populações americanas. Contudo, a alternativa de formação e reprodução social das elites em solo americano colocava em cheque não somente os interesses da Coroa, mas, também, o das elites dirigentes brasilicas. 

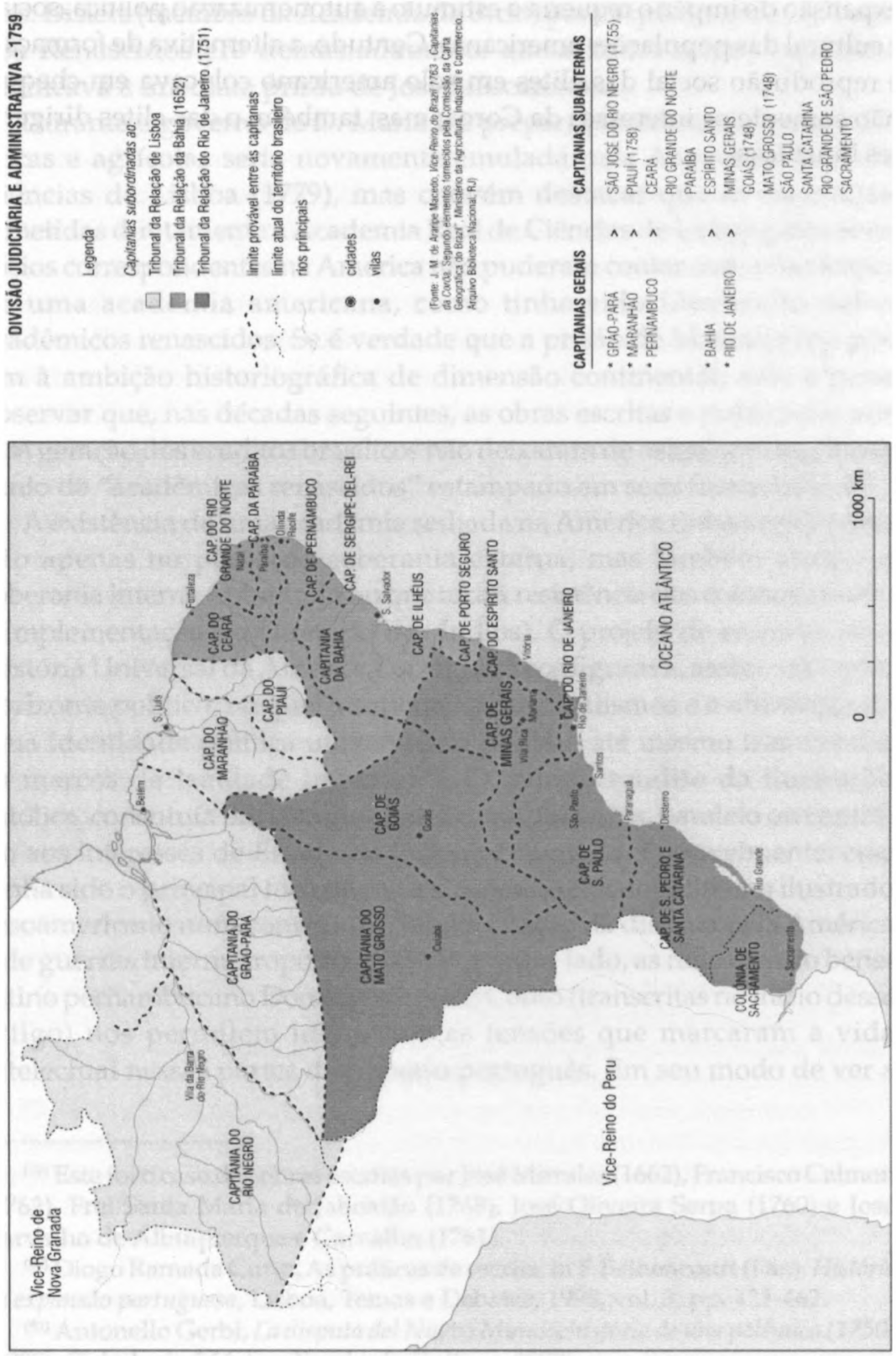

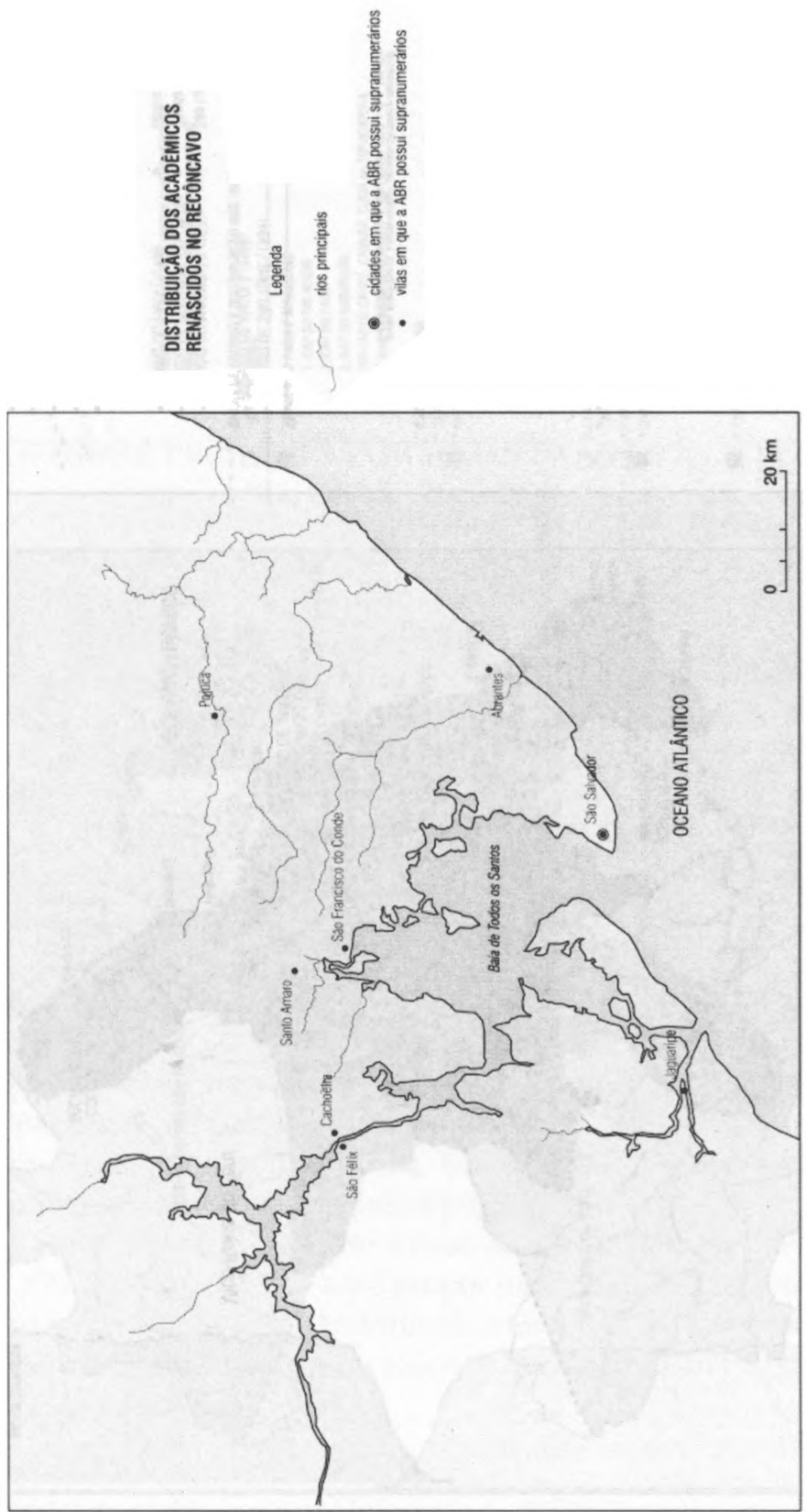

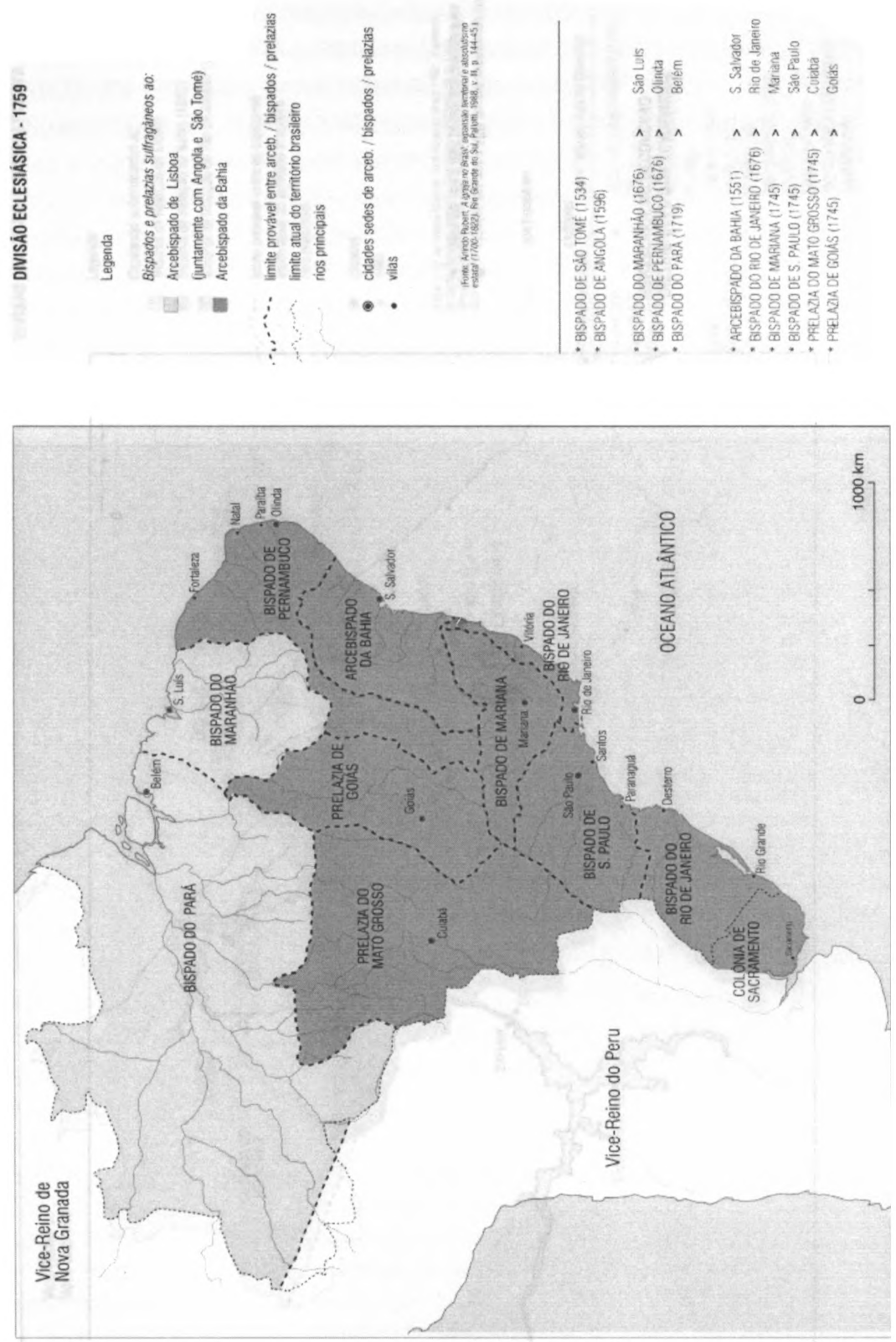

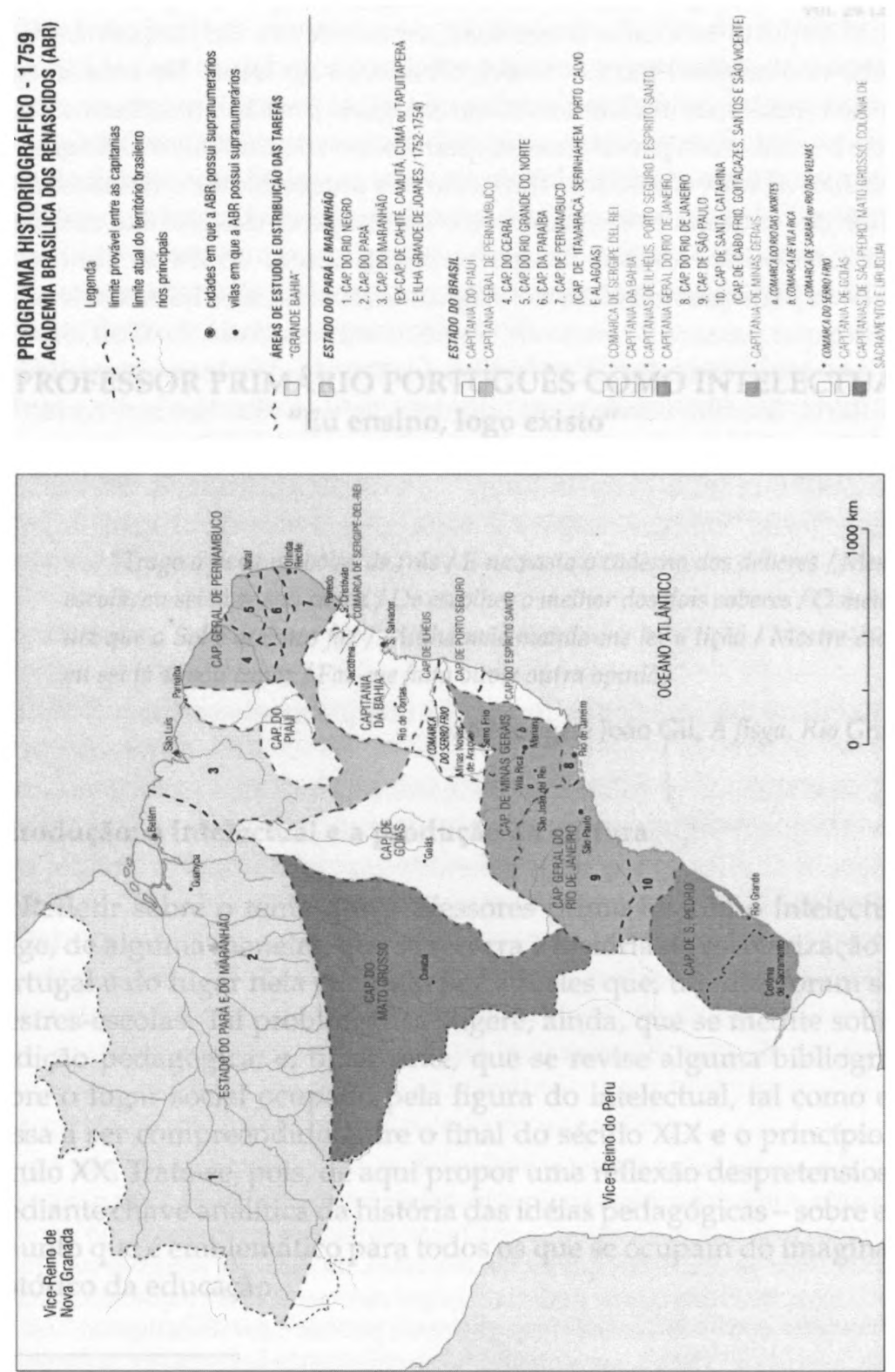